\title{
Editorial
}

\section{Definitions of place branding - Working towards a resolution}

Place Branding and Public Diplomacy (2010) 6, 1-10. doi:10.1057/pb.2010.3

\section{INTRODUCTION}

As readers of Place Branding and Public Diplomacy are well aware, the question of terminology is a vexed one in this field, and no term seems more problematic than 'brand/branding' itself. The definition of this elusive term, and the appropriateness of its application to nations, cities and regions, is a question to which this author has returned on many occasions in his own writing.

It is also, of course, the central question of this journal, and it has almost become a 'family joke' at Place Branding and Public Diplomacy that so many papers submitted to the Journal begin by quoting the well-known definition of 'brand' from the American Marketing Association dictionary ('A name, term, design, symbol, or any other feature ...' and so on). Clearly, many of our contributors feel that this is a new concept that still needs defining.

It is difficult to see how a field of study or practice can mature unless some kind of consensus is reached on the definition of the field, so the issue is long overdue for resolution. We need to move on.

In the hope of starting a process that might result in some such consensus, the editorial preface to this first issue of the sixth volume of Place Branding and Public Diplomacy represents an attempt to resolve some of the confusion surrounding the use of the term 'brand/branding' in the context of place reputation and image. Any further contributions to this discussion in the form of papers, opinion pieces, letters or other commentary will be most welcome, and, wherever space permits, will be published in subsequent issues of the journal.

\section{CAN A PLACE BE A BRAND?}

Parallels between places and products go back a long way, of course. Places have been promoting their attractions and their images throughout history, because they have always needed to attract settlers, customers, visitors, traders, investors and the category of people we today call 'influencers'.

Perhaps this need was never more evident, and neither was the rivalry between places more fierce, than in North America during the late nineteenth and early twentieth centuries, as development spread across the United States and Canada, and competition for new residents, businesses, and especially investors in land and property became vigorous among the smaller settlements. The great English comic writer, P.G. Wodehouse, for whom such competition between places was an unfamiliar concept, poked fun at American 'boosterism' in the early years of the twentieth century (the speaker is his celebrated creation, the valet Jeeves):

I happened last night, sir, as you had intimated that you would be absent from 
home, to attend a theatrical performance, and entered into conversation between the acts with the occupant of the adjoining seat. I had observed that he was wearing a somewhat ornate decoration in his buttonhole, sir - a large blue button with the words 'Boost for Birdsburg' upon it in red letters, scarcely a judicious addition to a gentleman's evening costume.

To my surprise I noticed that the auditorium was full of persons similarly decorated. I ventured to inquire the explanation, and was informed that these gentlemen, forming a party of eighty-seven, are a convention from a town of the name of Birdsburg, in the State of Missouri. (Wodehouse, 1917)

As marketing matured from art to science in the consumer boom years following the second World War, amateur boosterism gradually developed into professional place marketing; and the promotion of places has continued to move forward in parallel with the promotion of products and services ever since, with place marketers adopting the new techniques of product marketers, more or less as soon as they appear. Nonetheless, it took a surprisingly long time before place marketers began to apply the notion of brand to their work.

Strategic place marketing, a concept developed by Kotler et al (1993), was among the first to take the explicit position that places needed to run themselves like businesses, and market themselves like businesses, if they were to respond adequately to the threats of global competition, technological change and urban decay.

The question of place image is certainly touched upon and its importance acknowledged in Kotler's early work, but place marketing is still seen fundamentally as a tool for selling the products and services and attractions of the place more effectively, and not for tackling the overall image or reputation of the place in any direct way. Indeed, the American Marketing Association's Dictionary today contains the following definition of place marketing:

Marketing designed to influence target audiences to behave in some positive manner with respect to the products or services associated with a specific place.

This definition is followed by the rather tart comment:

Attempts by an individual or organization to educate target audiences or change their attitudes about a place are not marketing.

... with a reference pointing the reader to 'public relations' in the adjoining column.

The implication appears to be that marketing - the development, promotion, distribution and sale of products and services - is a legitimate, tangible and measurable activity with direct business benefits, a 'real job', one might say, whereas brand is an academic construct, a psychological process, a phenomenon for observation rather than a discipline to be practised. In a sense, the Dictionary does marketing a disservice by suggesting that attitude and image change are alien concepts: the key distinction is surely whether attempting to bring about attitude or image directly is within the province, or the capabilities, of marketing. There is no doubt or any shortage of proof that changes of attitude and image can occur as a result of the successful marketing of products and services: in other words, as an indirect consequence of marketing.

City marketers, especially in North America, have tended to be quicker off the mark than their counterparts on other continents when it comes to learning and borrowing from the newest commercial practices; and the administrations and governments of larger communities such as regions and nations have only started to recognise the relevance of these topics to their work much more recently. It is relatively common now for city governments in richer countries to have an individual or even a department dedicated to the job of promoting the city as a whole 
(as distinct from the tourist board and investment promotion agency, which are usually separated from the executive), whereas such roles are still rather rare in national governments and administrations.

Thanks to the advance of globalisation, competition between places today extends well beyond North America and certainly affects more than just cities: subnational and supranational regions, states and provinces, nations, towns and even villages now find themselves competing for the same people, products and capital; their products, services and people also compete externally for consumers, respect and media attention.

Kotler's position was prophetic. No place, it seems, can now think of surviving, let alone prospering, unless it knows how to wield the weapons of business.

\section{FROM PLACE MARKETING TO PLACE BRANDING}

Brand theory appears finally to have reached the governments of cities and countries from commercial practice, and to have done so principally through two routes: tourism and export marketing.

It is no surprise if tourism has the strongest connections with commercial marketing, as the tourist board is fundamentally a marketing outfit. There has been a lively exchange of best practice between commercial marketing and 'destination marketing' for many decades, and indeed the term 'destination branding' has been in use for at least a decade (although it is also the cause of considerable extra confusion, it is often wrongly conflated with 'place branding' or 'nation branding').

One could go further and argue that no transition from 'private sector' to 'public sector' has actually taken place in the case of tourism because it is already in the business of promoting and selling services to mass consumers, both domestic and foreign, in the open market. The fact that the goods or services on sale are often the property and the responsibility of the state rather than privately owned by the marketer is a mere detail; in most market economies, the government simply provides an umbrella 'brand' over the private providers of privately owned and privately marketed services, destinations and attractions.

Seen from this perspective, the transition from destination marketing to destination brand is all the more logical because the state or region is generally responsible for the overall place image, leaving the marketing of specific services to the end-user to private operators. If the private operators are the dots, the job of government is to join them up in the end-user's mind.

As Nicolas Papadopoulos noted in his essay in the first edition of Place Branding and Public Diplomacy (Papadopoulos, 2004), a clear line can also be drawn from the 'country of origin effect' to place branding (Anholt, 1998). In a similar way to tourism, export is a sector consisting mainly of private operators independently marketing their own goods and services directly to consumers, but with an 'umbrella' effect provided by the state. For this reason, export marketing forms another bridge between the state and the private sector, and it is easy to see how expertise in promoting the products of a certain country leads, via the observation that a positive country image provides a powerful brand asset to that country's exports, to the conclusion that the country's image needs management just as a corporation's or product's brand needs management.

Other sectors act in a similar way, such as foreign direct investment promotion (the main difference here being that the marketing is exclusively business-to-business), with the country or region playing the role of the 'corporate' brand above the level of the individual provider or location; and the cultural sector, where services in the form of artistic endeavour, events and entertainment are exported (or foreign consumers 'imported' to enjoy them), and marketed to those end-users. 


\section{IS A PLACE NAME A BRAND NAME?}

As the cases of tourism and export marketing indicate, there is no question that the concept of brand is relevant and useful to places, both at the sectoral level and in their roles as 'umbrella brands' providing reassurance, glamour or status to the products and services that are marketed under their aegis. A positive place image, in short, makes it cheaper and easier for producers to export and attract.

Yet, however logical the comparison of place to product might be, and despite the evident benefits that competent and professional management and promotion can bring to the citizens of the place, the comparison never fails to attract its critics and cynics.

One fairly straightforward objection to the characterisation of places as brands is based on the contention that, although products are deliberately branded for the purposes of sale, places are not given their names for this reason - they are simply called what they are called - and therefore to describe a place-name as a brand-name is inappropriate and misleading.

This contention, incidentally, rests on a simple interpretation of 'branding' which remains very close to the word's original root: the marking of livestock with the owner's name or sign, in which owners actively brand their possessions with their name in order to establish their ownership and avoid confusion with other people's possessions; such an act, it is argued, cannot (or perhaps should not) apply to a community of people.

But this argument fails on two counts. Firstly, there are plenty of commercial products and corporations, which, like many places, have never been deliberately branded, and have simply inherited their brand names: Heinz, Hewlett-Packard, Black \& Decker and Waterstones, for instance, are simply makers' or founders' names that became trademarks, and hence brands.

Secondly and conversely, there are plenty of places that have been quite deliberately branded in order to sell themselves more effectively to a specific audience.
Greenland, according to one popular account, was given its name by Erik the Red in order to attract settlers to the territory by giving it an impression of greater fertility than the place actually possessed, and although the region was in fact much greener 1000 years ago than it is today, nonetheless, the deliberate attempt to depict the place in an attractive light is undoubted. Formosa, the previous name for the island of Taiwan (meaning 'beautiful' or 'shapely'), Venezuela (meaning 'little Venice') and the many places named Esperanza ('hope'), quite clearly fall into the same category; likewise Liberia (based on the Latin root signifying 'freedom', an appropriate name for the new homeland of freed American slaves), is quite clearly the deliberate application of a constructed term onto a place in order to invest that place with a particular public meaning and attraction. Liberia's capital, Monrovia, could equally be described as a branded place, as it is named in honour of James Monroe, the fifth American president and a staunch supporter of the colony in its early days. Such places are branded - their names packed with symbolic meaning in the hope of influencing the opinions and actions of both external and internal audiences - in much the same way as the products and corporations of Nike, Timberland, EasyJet or Swatch are branded.

Cities are quite commonly branded in this way, usually to immortalise the memory of a founder, conqueror or ruler, and a handful of countries too, such as Bolivia (but note that Simón Bolívar's own name itself derives from the name of a village in Spain where, presumably, his ancestors came from - so there is a great circle of buried meaning in the country's name). The Seychelles were named after the Finance Minister of Louis XV, Alexandria after Alexander, Colombia after Columbus, America (reputedly) after Amerigo Vespucci, the Philippines after Philip II of Spain, Virginia after the (virgin) Queen Elizabeth I, and a host of other cities, regions and countries after their discoverers or colonisers, or their discoverers' or colonisers' monarchs or patrons; the practice continues 
into modern times with names like Saudi Arabia and Ho Chi Minh City. These 'propaganda names' are often intended to brand the giver of the name more than the place itself, which, arguably, is a very explicit form of branding in the original sense of the word - it is territorial marking as cattle branding is property marking, and isn't much more sophisticated than a dog urinating on a tree.

The other common type of colonial name is simply a reminder of home, such as New Zealand, New England, New York and the vast majority of English town, city and state names in North America, Australia, South Africa and New Zealand (not to mention Portuguese names in Mozambique, Spanish names in Mexico, Dutch names in Indonesia, French names in England, Arabic names in Spain, and so forth almost ad infinitum). These names also performed a branding role, in that their purpose was often to create an association with another more 'civilised' place, and thus give reassurance (or perhaps merely hope), both to cheer up lonely pioneers and to attract further colonists.

Some country names, on the other hand, are more complex constructs or word games, carefully designed to communicate some desired meaning to the attentive observer, Pakistan being the best example of this category (the name was constructed by Choudhary Rahmat Ali in 1933 as an acronym of Punjab, Afghania, Kashmir, Indus Valley, Sindh, Turkharistan, Afghanistan and BalochistaN).

Other countries have undergone more recent 'rebranding' to names that incorporate a special significance, such as Burkina Faso a word constructed from two of the country's principal languages, meaning 'land of upright people', 'land of honest men' or 'land of the incorruptible' (Burkina from the More language and Faso from Dioula). Tanzania, more prosaically, simply accreted the names of its two regions - Tanganyika and Zanzibar - when they were united. In a similar way, the city of Mexicali in Northern Mexico, and Calexico, its near neighbour on the US side of the border, combine the names of Mexico and California in inverse order, although in these cases the portmanteau names were intended as gestures of neighbourly goodwill, rather than statements of territorial integrity.

It is natural that when a leader or a people get the chance to rename their country they will select or construct a name that contains some branding power - a vision, a purpose, a political direction, an interpretation of history - whereas a country whose name has remained constant for many generations is more likely to be a non-deliberate one, or at least a deliberate one whose purpose has been forgotten or no longer applies (it has been many years since Rubbermaid made rubber products, or people knew what a maid was, or why Grape-Nuts contain neither grapes nor nuts, but the loss of these original associations does little to weaken the two brands).

Many older country names are given after the people who live there - France (land of the Franks), England (land of the Angles), Tajikistan (land of the Tajiks) - whereas others are merely functional descriptions of the country's location - Australia (southern continent), South Africa, Ecuador (equator) - and although such names certainly acquire brand equity over time, mainly as a result of the behaviours of their inhabitants, they cannot be truly said to be deliberately created brands.

Other country names are descriptive of the physical aspect that the country first presents to the visitor or colonist, such as Albania (the white country - referring to its mountain peaks), the Faroe Islands (the 'island of sheep' in Faroese), Anguilla (shaped like an eel), Tuvalu (eight islands), and here it is harder to be sure that their names were not once deliberate acts of (tourism or immigration or investment) marketing.

Another category of place name owes more to superstition, religion and the natural anxieties of explorers and colonists on lonely and dangerous voyages far from home. Many islands, for example, bear 'good luck' names, typically the names of gods or saints applied in order to propitiate, thank or honour some 
supernatural being: the numerous Caribbean and Pacific islands named after Catholic saints by Spanish explorers and colonists are one example, but the habit goes much further back: the Isle of Man, for example, derives its name from Manannán mac Lir, the Brythonic and Gaelic equivalent of the god Poseidon. The branding technique is familiar: good luck names of this sort are common enough in the corporate sphere too, especially in Asia, where brand names such as 'Lucky Boy Chilli Sauce' abound, the idea presumably being that the luck of the token will accrue to the user as a kind of added value for money. In the case of religiously inspired names, one might perhaps argue that this is equally a branding exercise, except that the 'target audience' is the deity rather than other humans.

Countries, of course, are subject to rebranding attempts, often following independence from a colonial power, just as products are occasionally renamed when their owners change, to 'reposition' them in the eyes of the world, or to avoid confusion with a similar-sounding brand. Examples include Myanmar, Taiwan, Sri Lanka and a number of Indian cities including Mumbai and Kolkata; there was even a campaign in Slovenia, some years ago, to rename the country 'Alpadria', in an effort to resolve people's perennial confusion between it and Slovakia.

These rebrands are even more difficult and expensive and slow to pull off as their equivalent in the commercial world, no matter how just (and justly supported) the cause might be. The connection between an object - whether place, product or person - and its signifier becomes remarkably strong over time, however illogical or inappropriate it might appear to be from a certain perspective (nobody much thinks of 'Nike' as a Greek goddess, of 'Heinz' as a German surname, of 'Amazon' as a South American jungle, of 'Starbucks' as a character in 'Moby Dick', or of the 'Carphone Warehouse' as a warehouse that sells phones for cars).

And in some cases, it is public opinion that rebrands countries, whether the countries like it or not. The Netherlands is finally giving up the struggle to be known by its proper name, and has started to accept the rule of the market - that you are called what people call you - which in this case is 'Holland'. Coca-Cola learned the same lesson many years ago - after many years of ignoring, resisting and even attempting to stamp out the popular nickname 'Coke', they finally recognised it for what it was - a flattering indicator of the intimacy people felt towards the product - and endorsed it by trademarking (and vigorously protecting it) ever after.

\section{IS A FLAG A LOGO?}

The word 'brand' is, of course, just as often used to describe the logotype, or the 'sign or symbol' as the AMA definition has it, as the product's name. Can such a definition of 'brand' be equally applied to places?

One can make a persuasive case that the flags of many countries, as well as the crests or other emblems of many cities and provinces, have often been designed to perform a persuasive or communicative function, both internally and externally, which is entirely analogous to the functions of a brand identity in the commercial marketplace: flags are usually loaded with national symbolism that sends a message of purpose or identity or aspiration both inwards, to the population, and outwards, to friends and enemies alike.

And just like the names of places, many of them are extremely effective vessels for containing brand image, creating an instant and rich emotional response in the 'consumer' immediately upon sight. The Swiss flag, for example, is a natural 'logo' (distinctive, graphically simple, instantly recognisable, easily reproducible and inherently elegant), as are the Stars and Stripes, the Union Jack, and the flags of South Korea, Jamaica, Japan, Kenya and several others. But even certain very generic flags, such as the green, white and red bars of the Italian flag, effortlessly trigger all the responses that the thought of the country itself tends to trigger in the imaginations of observers (the fact that this iconic image is strikingly 
similar to the flags of India, Niger, Senegal, Tajikistan, Iran, Hungary, Kuwait, Mali, Equatorial Guinea, Ireland, Mexico, Bulgaria, Madagascar and Ivory Coast only serves to show that a weak logo doesn't matter much as long as you have a great brand).

It's easy to see why countries are so often tempted to create new logos for themselves these days. Just as Slovenia wanted to change its name in order to avoid confusion with a similar-sounding neighbour, many countries feel the need for a more distinctive 'logo' than their flag, which may be frustratingly similar to others. The Netherlands is one such example: its flag is, to most people, absolutely indistinguishable from that of half-a-dozen other countries, and under such circumstances it's easy to see the attraction of a tulip logo. Most national flags, in any case, were designed in circumstances and by people for whom qualities such as distinctiveness, fast and simple communication, memorability, creativity and so forth were hardly considered pre-eminent. In our globalised age, in which national profile has become so important and competition between places the order of the day, something much more like a logo may well seem more appropriate.

\section{WHAT IS PLACE BRANDING?}

So a case can certainly be made that many place names are a type of brand name: people respond to them as they respond to brands, they can acquire and lose equity like brands, and in some cases they are even deliberately coined as brands. Without stretching the point too far, one can also claim that those place 'brands' are often accompanied by visual identities, just as product brands have their logos.

However, when most people talk about place branding, they aren't usually talking about giving a name or a symbol to a place, because places already have names and many already have symbols: they are talking about doing something to enhance the brand image of the place: place branding is believed to be a way of making places famous.
It has long been this author's contention that it is both logical and legitimate to draw parallels between the brand image of a product or corporation or service, and the image of a country or city or region - because both depend to a great extent on the health and power of that image - but the question of how to manage or enhance that image is a much more complex question, and direct parallels between commercial practice and the management of places need to be made with considerably more caution. The development from place promotion to place marketing and thence to place brand are all relatively straightforward logical transitions; it is the transition from place brand to place branding that presents the most serious conceptual and practical difficulties.

The noun 'brand', as the American Marketing Association definition shows, is not especially hard to define in the context of products and services, as long as one sticks to the non-psychological aspects of the concept. From this definition, most variants on the term spring quite naturally: a 'branded' product is one to which such a name or sign has been given, whereas an 'unbranded' product is one which remains un-named and un-signed. 'Brand equity' is the value inherent in the name or sign. 'Brand loyalty' is the preparedness of the consumer to give preference to products bearing that name or sign; and so forth.

'Brand image', however, is a concept that involves straying from observable reality into the world of perceptions, and keeping a firm grip on meaning starts to become harder. 'Brand image' is the set of beliefs or associations relating to that name or sign in the mind of the consumer (and here, it should be noted in passing, lies one source of a great deal of confusion: the fact that the word 'brand' is often used interchangeably with 'brand image', even though the concepts are really rather different, the former being within the domain of the product and consequently under the control of the producer, and the latter being within the 
domain of the consumer, and thus outside the direct control of the producer).

Unfortunately, common usage is always less precise than dictionary definitions. Outside the dictionary, the word 'brand' tends to be used to mean at least four different things. The first two are covered by the AMA definition quoted previously: firstly, it can refer to the name of the product, and secondly to its designed identity (the look of the product itself, its packaging, its logo, its livery, and so forth). Thirdly, 'brand' is sometimes used more ambitiously to refer to the culture of the organisation behind the product (as in the phrase 'living the brand'). Fourthly, as just discussed, it is often used as a synonym for brand image, referring to the product's or corporation's reputation in the minds of its target audience (this, incidentally, is the sense in which this author used the word in his 1998 paper mentioned earlier, although in hindsight the term 'brand image' would have been a more precise one in this context and might have saved a great deal of confusion later on).

The trouble really starts when verb forms are produced from the noun: to brand; or the act of branding; even rebrand/rebranding. Somehow, a verb constructed on the basis of an imperfectly understood noun appears to compound the misunderstanding, but perhaps one can try to work backwards from the verb and see which of the common substantive meanings it derives from.

Thus, one might suppose that branding is related to one or another of the four common usages of 'brand' listed above: it is surely either (a) the business of naming products; or (b) designing the livery of products (and these first two activities are indeed what a branding agency does); or (c) it has something to do with building or creating an enhanced sense of corporate culture or 'mission' within the organisation (in fact the word is not often used in this context); or (d) it is the means by which the product acquires its reputation. As we shall see later, it is this last meaning (or supposed meaning), which is tending to become the pre-eminent meaning in the context of place branding, and in the view of this author, it is the most problematic, the most flawed of all the word's possible meanings.

\section{IS PLACE BRANDING SIMPLY CORPORATE IDENTITY FOR PLACES?}

However, before tackling the question of whether it is legitimate or meaningful to talk of 'branding' a place in the sense of enhancing its brand image, there is another common interpretation of the verb which must be mentioned. This is, like the earlier remarks about flags as logos, an interpretation based on the idea of brand as 'sign or symbol', but it is an even more humdrum business which, if it were indeed the only or principal meaning of the phrase, wouldn't begin to justify the excitement about 'nation branding' or 'place branding', and this journal would certainly have not been able to fill six volumes.

Countries, through their many state agencies, have numerous dealings with various professional audiences around the world, and one can certainly argue that it gives a better impression of the country if all those agencies use consistent, well-designed materials when they carry out their transactions. A single logo, a professional 'look and feel' on their stationery, business cards, corporate videos, information leaflets, communiqués, press releases, websites and so forth, undoubtedly reinforce the impression of a well-organised, modern, self-respecting state with effective and efficient structures, processes and mechanisms.

If this is 'nation branding' then it is indeed hard to object to it on any grounds: it's an eminently sensible, perfectly achievable standard to aspire to; all countries should try to do it well; and it's certainly as important as, for example, making sure that diplomats offer the right kinds of canapés when entertaining foreign heads of state; but it's hard to understand why anybody in their right mind would want to spend time theorising about it, still less write books about it.

The point is that 'nation branding' in this sense of the term is essentially a passive 
operation: it cannot win any new customers, change anybody's mind, increase market share, or affect the country's prospects in any significant way. It is simply good practice, a useful exercise of reassurance, a piece of housekeeping.

So why all the fuss? Certainly, for low-cost, fast-moving consumer products in a busy retail environment, this kind of 'branding' can be almost as important as the product itself, because design is one of the few things that distinguish a product from its competitors; the attractiveness of the product and its wrapper may even be a more significant driver of consumer choice than advertising. This is why branding agencies, accustomed to the emphasis placed on brand identity in their native field of commerce, talk so impressively about such matters, and public officials are often swayed by their talk. But countries aren't for sale, aren't easily mistaken one for another, aren't fast-moving consumer goods, and certainly don't come in wrappers, so the principles simply don't transfer.

It certainly appears to this author that in a great many of the instances in which countries and cities claim to be undertaking 'branding' exercises, what they actually mean is nothing more than this modest process of livery enhancement and coordination. This would be harmless enough if they fully realised the limited extent of its potential benefits, but it often appears that they don't. The fact that part of the preparatory work towards creating a visual identity or corporate livery often involves a fairly intensive analysis of the 'core meaning' or 'central identity' of the thing being branded only helps to deepen the confusion about the importance and scope of such an operation. Either through their own lack of understanding, or through the persuasive abilities of branding agencies most likely a combination of the two - many governments end up believing that the practice of nation branding corresponds to this simple design and print process, but they somehow also believe that its effect will be to make the place more famous.
This assumption overlooks the important question of how international mass opinion is even going to hear about the exercise, let alone be swayed by it: but such is the confusion and vagueness surrounding the concept of brands and branding, it is often believed that the addition of other so-called 'branding' techniques, such as advertising, marketing, public relations, web design and social networking, will somehow see to this. So a lot of deep discussion about the country's identity, followed by the design of a logo, and a campaign of expensive media promotion to 'launch' or 'communicate' the new 'brand' is usually sufficient to persuade governments that they are on their way to permanently improving the international image of their country.

They are, of course, quite wrong, and if there were a single instance of a country that had demonstrably 'moved the needle' on its international image simply through the creation and dissemination of a new visual identity, one can't help feeling that it would be well known. But nobody this author has ever encountered in 15 years of study and practice in this field has ever been able to produce such an example, and until such an example is produced, it seems more prudent to assume that countries are judged as they always have been: by the things they do, not by the things they say.

\section{WHY PLACE BRANDING IS A CHIMAERA}

The fundamental confusion stems from the idea that 'branding' means a technique, or set of techniques, by means of which brand image is directly built or enhanced: 'Nike's fantastic brand image is the result of fantastic branding'. It is not. Nike's fantastic brand image is the result of fantastic products sold in fantastically large numbers, accompanied by communications that encourage consumers to identify with the 'values' of the company. This is using 'branding' as a kind of generalised or collective term to embrace all the techniques used to enhance brand image - PR, advertising, design, 
sales promotion, direct marketing and so forth - but this is not correct: the correct portmanteau word for such activities is surely 'marketing communications' or 'promotional activities'.

Brand building is primarily achieved through product development and marketing, and has relatively little to do with branding (except, as mentioned before, if branding means logo and packaging design for certain consumer goods, in which case it certainly helps the marketing process along). If people buy a product and find it good, this will begin to create a powerful brand image for the product; the product will earn a good reputation. This reputation gradually spreads to non-users; even people who haven't bought the product will know, or feel they know, that it is a good product. The reputation spreads, drives up sales, and increases the value of the corporation. It is certainly one of the most significant factors of business success.

But the use of the term 'branding' to imply some distinct and direct method for building brand equity (as opposed to a general term covering all marketing communications techniques) is both incorrect and unjustifiable; there is simply no such method. Good products and services produced by a good corporation acquire a positive brand image, which eventually reflects on the corporation and becomes its principal asset.

Branding, in other words, is a process that goes on largely in the mind of the consumer - the accumulation of respect and liking for the brand - and cannot be seen as a single technique or set of techniques that directly builds respect or liking. Marketing communications create interest, which results in sales, which results in consumer experience of the product, which, if satisfactory and shared, results in brand equity. This natural, indirect process can sometimes be enhanced by public relations - by influencing the media in such a way as to reinforce the sense that the consumer experience is positive and shared - but this is no short cut to changed perceptions.

Similarly, good products, services, culture, tourism, investments, technology, education, businesses, people, policies, initiatives and events produced by a good country also acquire a positive brand image, which eventually reflects on the country, and perhaps also becomes its principal asset.

The message is clear: if a country is serious about enhancing its international image, it should concentrate on the national equivalents of 'product development' (and the effective and professional marketing of those 'products') rather than chase after the chimaera of branding.

There are no short cuts. Only a consistent, coordinated and unbroken stream of useful, noticeable, world-class and above all relevant ideas, products and policies can, gradually, enhance the reputation of the country that produces them.

\section{REFERENCES}

American Marketing Association Dictionary, see http://www .marketingpower.com/_layouts/Dictionary.aspx.

Anholt, S. (1998) Nation brands of the twenty-first century. Journal of Brand Management 5(6): 395-406.

Kotler, P., Haider, D.H. and Rein, I. (1993) Marketing Places: Attracting Investment, Industry and Tourism to Cities, States and Nations. New York: The Free Press.

Papadopoulos, N. (2004) Place branding: Evolution, meaning and implications. Place Branding 1(1): 36-49.

Wodehouse, P.G. (1917) Jeeves and the hard-boiled egg. The Strand Magazine, London.

Simon Anholt Managing Editor 